\title{
Solvent-cast polymeric films from pectin and Eudragit $₫$ NE 30D for transdermal drug delivery systems
}

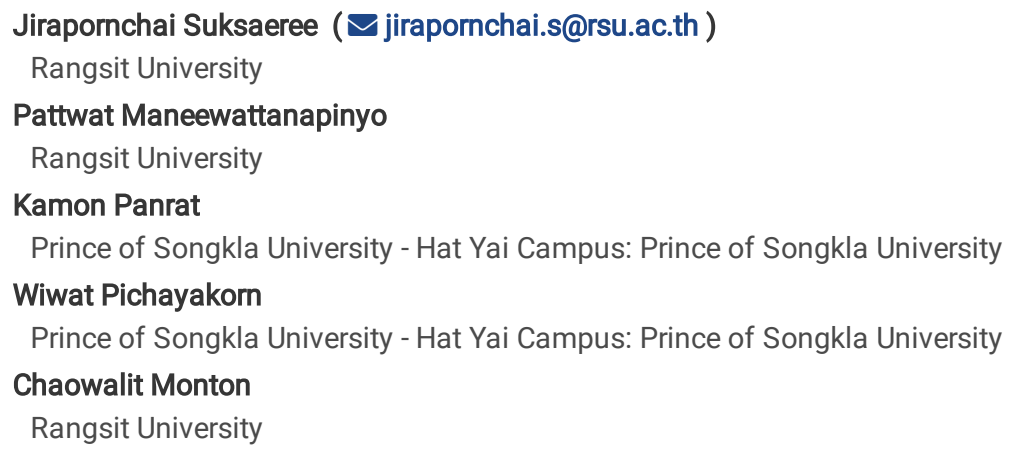

Keywords: Pectin, Eudragit ${ }^{\circledR}$ NE 30D, ionic liquid drug, solvent-cast polymeric films, transdermal drug delivery systems

Posted Date: February 17th, 2021

DOI: https://doi.org/10.21203/rs.3.rs-204609/v1

License: () (1) This work is licensed under a Creative Commons Attribution 4.0 International License. Read Full License

Version of Record: A version of this preprint was published at Journal of Polymers and the Environment on March 9th, 2021. See the published version at https://doi.org/10.1007/s10924-021-02108-3. 


\section{Abstract}

In this study, solvent-cast polymeric films containing ionic liquid lidocaine/aspirin for transdermal patches were developed. Solvent-cast polymeric films were prepared from two polymers, pectin and Eudragit ${ }^{\circledR} \mathrm{NE} 30 \mathrm{D}$, by drying the polymeric solution in a hot air oven at $70 \pm 3^{\circ} \mathrm{C}$ for 10 hrs. Glycerin was used as a plasticizer. Lidocaine and aspirin were prepared in ionic liquid form and loaded into the patches. The physicomechanical properties of the films were characterized by texture analysis, differential scanning calorimetry, thermogravimetric analysis, and X-ray diffraction. A scanning electron microscope was used to photograph the surfaces of solvent-cast polymeric films. Eudragit ${ }^{\circledR} \mathrm{NE} 30 \mathrm{D}$ significantly decreased the toughness and rigidity of the films. The transdermal patches were in the amorphous state, and their thermal properties were not changed from blank polymeric films. The surfaces of transdermal patches were rougher than blank polymeric films and revealed the distribution of the drug. Eudragit ${ }^{\circledR} \mathrm{NE} 30 \mathrm{D}$ significantly decreased the trends of entrapment efficiency and in vitro release of lidocaine and aspirin drugs. The kinetic release observed in vitro fitted to Higuchi's model rather than zero and first order models, indicating that a diffusion mechanism governed the release of the drug from the patch. Thus, the solvent-cast polymeric films from two polymers, pectin and Eudragit ${ }^{\circledR} \mathrm{NE} 30 \mathrm{D}$, are suitable for transdermal patches loaded with ionic liquid lidocaine/aspirin.

\section{Introduction}

Film preparations are widely used in pharmaceutical dosage methods and as drug delivery systems. They are used as packaging materials, tablet coatings to protect drugs from environmental factors, and matrix layers to control the release of the drug, among others. Polymer films are also used in the preparation of transdermal formulations for delivering drugs to the skin, e.g., polymethylmethacrylate for lidocaine hydrochloride (1), ethyl cellulose blended with deproteinized natural rubber latex for ketoprofen patches (2), deproteinized natural rubber latex-based polymer blends (3-6) and pectin-based polymer blends for nicotine patches (7-9), chitosan-based polymer blends for Thai herbal patches (10, 11), and polydimethylsiloxane and ethylcellulose for centchroman patches (12). These polymeric matrix drug-containing films can be used in treatment where drug release must be controlled and provide increased drug concentrations through the skin into the blood. The advantages of polymeric matrix films include ease of preparation and application to the skin, good physicochemical properties and flexibility, stability, and compatibility with the drugs and the skin. The polymeric matrix film is prepared by solvent casting, and the solvent evaporates from the polymer solution. Traditionally, organic solvent was most commonly used to prepare the polymeric matrix film due to easy evaporation, but today, the organic solvent-based polymeric film has been replaced largely by water-based polymeric film. Organic solvent-based films are considered undesirable for pharmaceutical use because of the difficulty in removing the solvents completely, stringent regulations on exposure to these solvents, and strict guidelines on discharge of organic solvents due to increased environmental concerns (13).

Previously, we reported the preparation of polymeric matrix films from pectin isolated from durian fruit-hulls (9) and Cissampelos pareira (Krueo Ma Noy) leaves (8) to control the release of nicotine. Pectin was found to be a suitable polymer for the preparation and controlled release of the drug. However, isolating the pectin required significant and challenging labor. Fortunately, the properties of polymeric matrix films made from isolated pectin have been compared with commercial pectin, and their properties do not significantly differ (7). Thus, commercial pectin is promising for the preparation of polymeric matrix films and blending with Eudragit ${ }^{\circledR} \mathrm{NE} 30 \mathrm{D}$. Available as a 30\% aqueous dispersion of a neutral copolymer based on ethyl acrylate and methyl methacrylate, Eudragit ${ }^{\circledR}$ NE 30D has been reported for modified and controlled release formulations of various drugs, e.g., zolpidem tartrate (14), loratadine (15), prednisolone (16), and miconazole nitrate (17). Hence, we selected Eudragit ${ }^{\circledR} \mathrm{NE} 30 \mathrm{D}$, a versatile polymer for drug delivery, to blend with pectin in the current study.

Ionic liquid drugs are widely utilized in pharmaceutical applications, e.g., acetylsalicylic acid-salicylic acid (18), lidocaine-etodolac (19), lidocaineibuprofen $(20,21)$, and lidocaine docusate-lidocaine hydrochloride (22), that modify the solubility, increase the thermal stability, and enhance the efficacy of topical analgesia compared with their starting materials. In addition, ionic liquids have been used as active pharmaceutical ingredients or formulation preservatives to increase antimicrobial activity $(23,24)$. Our previous study reported the preparation and characterization of the ionic liquid form between lidocaine and aspirin (25).

In this study, we assessed the feasibility of preparing the solvent-cast polymeric films containing liquid ionic lidocaine/aspirin for transdermal patches. The effects of variable ratios of pectin and Eudragit ${ }^{\circledR} \mathrm{NE} 30 \mathrm{D}$ on the physicomechanical properties and in vitro release were studied, with glycerin used as a plasticizer. Texture analysis, differential scanning calorimetry (DSC), thermogravimetric analysis (TGA), and X-ray diffraction (XRD) were used to evaluate solvent-cast polymeric films for transdermal patches. The surface of the solvent-cast polymeric films for transdermal patches was photographed using a scanning electron microscope (SEM). Finally, drug release from the polymeric matrices of the transdermal patches was assessed.

\section{Materials And Methods}

\subsection{Materials}

Lidocaine hydrochloride, aspirin, and glycerin were purchased from Sigma-Aldrich, USA. Pectin was purchased from VR Bioscience Co., Ltd, Thailand. Eudragit ${ }^{\circledR}$ NE 30D was obtained from Jebsen \& Jessen Ingredients (T) Ltd., Thailand, as a gift for this work. All chemicals were of analytical 
grade, obtained from Merck KGaA, Germany.

\subsection{Preparation of solvent-cast polymeric films containing ionic liquid lidocaine/aspirin for transdermal patches}

First, the aspirin drug was transformed into an aqueous aspirin sodium salt form by dissolving $10 \mathrm{mmol}$ of aspirin powder and $10 \mathrm{mmol}$ of sodium hydroxide in $100 \mathrm{~mL}$ of distilled water. Aqueous aspirin sodium salt was then combined with 10 mmol lidocaine hydrochloride to form an ionic liquid, using the following technique. Ten mmol of lidocaine hydrochloride was slowly added and heated at $80^{\circ} \mathrm{C}$ for $2 \mathrm{hrs}$. The solution was extracted in 100 $\mathrm{mL}$ of dichloromethane and washed with distilled water to remove inorganic salt. The dichloromethane solvent was removed by rotary evaporator and kept in a chemical fume hood for one day and in a low-pressure chamber ( $<400 \mathrm{~mm} \mathrm{Hg}$ ) for 10 min to obtain the viscous light-yellow ionic liquid lidocaine/aspirin drug. This prepared ionic liquid lidocaine/aspirin was checked the residual solvent of the dichloromethane by gas chromatography and the chloride ions by silver nitrate test. The residual solvent of the dichloromethane was not found in prepared ionic liquid lidocaine/aspirin and no chloride ions were detected using the silver nitrate test, as reported in our previous study (25).

The prepared ionic liquid lidocaine/aspirin was loaded into solvent-cast polymeric films for transdermal patches. The compositions of solvent-cast polymeric films are shown in Table 1. Briefly, the pectin powder was dissolved in distilled water to obtain the clear solution and mixed with glycerin as a plasticizer. The Eudragit ${ }^{\circledR}$ NE 30D solution was slowly mixed into the solution, and the prepared ionic liquid lidocaine/aspirin was dissolved in the distilled water then added to the solution. Approximately 25 grams of the resulting clear solution was cast into Petri dishes with a surface area of $70.88 \mathrm{~cm}^{2}$. The water solvent was evaporated in a hot air oven at $70 \pm 3^{\circ} \mathrm{C}$ for $10 \mathrm{hrs}$. The solvent-cast polymeric films were peeled off the dishes and used in subsequent analyses.

\subsection{Characterization of solvent-cast polymeric films containing ionic liquid lidocaine/aspirin for transdermal patches}

A TA.XT Plus texture analyzer (Texture Technologies Corporation and Stable MicroSystems, Ltd., USA) was used to test the tensile strength of solvent-cast polymeric films containing ionic liquid lidocaine/aspirin for transdermal patches. The samples were cut into $1 \mathrm{~cm}$ ' $6 \mathrm{~cm}$ rectangles. The tested area of the sample was controlled as a $1 \mathrm{~cm}$ gauge length. The cross-head speed was controlled at $10 \mathrm{~mm} / \mathrm{min}$ with a maximum loaded cell at $50 \mathrm{kN}$. The ultimate tensile strength (UTS) and elongation at the break were determined.

The thermal behaviors of solvent-cast polymeric films containing ionic liquid lidocaine/aspirin for transdermal patches were studied using DSC (DSC7 instrument, Perkin Elmer, USA) and TGA (TGA7, Perkin Elmer, USA) methods. For DSC testing, approximately 10 mg of sample was weighed in the DSC pan and then hermetically sealed. The test conditions were $10^{\circ} \mathrm{C} / \mathrm{min}$ from $25^{\circ} \mathrm{C}$ to $300^{\circ} \mathrm{C}$ under a liquid nitrogen atmosphere. The $\mathrm{DSC}$ thermograms were generated, and the endothermic transition was observed. For TGA testing, $10 \mathrm{mg}$ of the sample was weighed into the TGA pan. The test conditions were $10^{\circ} \mathrm{C} / \mathrm{min}$ heating rate from $50^{\circ} \mathrm{C}$ to $500^{\circ} \mathrm{C}$ under nitrogen flushing with $100 \mathrm{~mL} / \mathrm{min}$ of gas flow. The TGA thermograms were generated, and the DTG was calculated.

The crystallinity of the solvent-cast polymeric films containing ionic liquid lidocaine/aspirin for transdermal patches was studied using MPD XRD (Empyrean, PANalytical, Netherlands). The test conditions were a generator operating voltage of $40 \mathrm{kV}$, an $\mathrm{X}$-ray source current of $45 \mathrm{~mA}$, an angular of $5-40^{\circ}(2 \theta)$, and a stepped angle of $0.02^{\circ}(2 \theta) / \mathrm{s}$.

The solvent-cast polymeric films containing ionic liquid lidocaine/aspirin for transdermal patches were cut into $1 \mathrm{~cm}$ ' $4 \mathrm{~cm}$ rectangles, immersed in liquid nitrogen, and the surface morphology photographed under SEM5800LV (model: JSM-5800 LV, JEOL, Japan) at an appropriate magnification.

\subsection{Determination of entrapped drug in solvent-cast polymeric films containing ionic liquid lidocaine/aspirin for transdermal patches}

The solvent-cast polymeric films containing ionic liquid lidocaine/aspirin for transdermal patches were cut into $1 \mathrm{~cm} \times 1 \mathrm{~cm}$ squares at different patch sites. The drugs were extracted by distilled water and sonicated for $90 \mathrm{~min}$, diluted with distilled water, and filtered through a $0.45 \mu \mathrm{m}$ cellulose acetate membrane. The extracted lidocaine and aspirin drugs were analyzed by HPLC instrument, and the results compared to the calibration curve of those drugs.

\subsection{In vitro release of solvent-cast polymeric films containing ionic liquid lidocaine/aspirin for transdermal patches}

The in vitro release study used a modified Franz-type diffusion cell apparatus. The effective diffusion area of the Franz diffusion cell was $1.77 \mathrm{~cm}{ }^{2}$. Isotonic phosphate buffer solution (12 mL, $\mathrm{pH}$ 7.4) was used as a receptor medium. The Franz diffusion cell was thermoregulated with a water jacket at $37 \pm 0.5^{\circ} \mathrm{C}$ and constantly stirred at $100 \mathrm{rpm}$ with a magnetic stirrer. The cellulose membrane molecular cut-off of 3500 was used as a partition between the donor and receptor compartments. The solvent-cast polymeric films containing lidocaine/aspirin for transdermal patches were cut and directly placed on a cellulose membrane. At sampling time, one $\mathrm{mL}$ of receptor medium was withdrawn, and the fresh receptor medium was immediately replaced with an equal volume. HPLC was used to analyze the drug content at different times. The in vitro experiments were performed in triplicate.

\subsection{Analytical method}


HPLC (Agilent 1260 Infinity system, Agilent Technologies, USA.) was used to analyze the drugs. It consisted of a quaternary pump system (Agilent, $1260 \mathrm{VL}$ ), autosampler (Agilent, $1260 \mathrm{TCC}$ ), and UV/VIS with diode array detector (Agilent, $1260 \mathrm{DAD}$ VL). The lidocaine and aspirin drugs were separated on reverse-phase ACE Generix 5 C18 column ( $4.6 \mathrm{~mm} \times 150 \mathrm{~mm}, 5 \mu \mathrm{m}$ particle size, DV12-7219, USA.). The HPLC system was operated in gradient elution mode at a flow rate of $1 \mathrm{~mL} / \mathrm{min}$. Acetonitrile and $0.01 \%$ of $85 \%$ orthophosphoric acid $(\mathrm{pH}=2.87$ ) were used as the $\mathrm{mobile}$ phase as follows: 25 to $70 \%$ of acetonitrile for $0-10 \mathrm{~min}, 70$ to $25 \%$ of acetonitrile for $10-11 \mathrm{~min}$, and $25 \%$ of acetonitrile for $11-14 \mathrm{~min}$. The injection volume was $10 \mu \mathrm{L}$. The UV detection was set at $220 \mathrm{~nm}$. The calibration curve was constructed by running drug standard solutions for every series of samples. Validation of the method was performed to ensure that the calibration curve between 10 and $100 \mu \mathrm{g} / \mathrm{mL}$ of lidocaine and aspirin drug solutions and peak areas were in the linearity range $\left(r^{2}>0.999\right)$ and intraday and interday coefficients of variation were less than $2 \%$. The validation method was described and reported previously by our research group (25). The validation results are shown in Table 2 . In addition, the blank patch was analyzed by the identical method to check the specificity and selectivity of the drug and ensure no interference from the patch components.

\subsection{Statistical Analyses}

The average value was calculated as a mean \pm standard deviation. All results were statistically analyzed by one-way analysis of variance followed by post hoc analysis. A $p$-value of less than 0.05 was considered to be statistically significant.

\section{Results And Discussion}

The preparation and characterization of ionic liquid drug of combined lidocaine and aspirin were reported previously by our research group (25, 26$)$. In the present research, the prepared ionic liquid lidocaine/aspirin was loaded into the solvent-cast polymeric film for transdermal patches. The weight and thickness of the solvent-cast polymeric films without loading the ionic liquid lidocaine/aspirin were $64.60-83.78 \mathrm{mg} / \mathrm{cm}^{2}$ and $211.20-232.00$ $\mu \mathrm{m} / \mathrm{cm}^{2}$, respectively. The lowest weight and thickness of the solvent-cast polymeric film was observed in the polymeric film prepared without Eudragit ${ }^{\circledR} \mathrm{NE}$ 30D. The weight and thickness increased by increasing the ratio of Eudragit ${ }^{\circledR} \mathrm{NE} 30 \mathrm{D}$ in the polymeric film due to the film's increasing solid content. Similarly, the weight and thickness of the solvent-cast polymeric films were slightly increased when lidocaine/aspirin was loaded. The weight and thickness of the solvent-cast polymeric films containing lidocaine/aspirin were $65.04-84.84 \mathrm{mg} / \mathrm{cm}^{2}$ and $214.40-235.60 \mu \mathrm{m} / \mathrm{cm}^{2}$, respectively (Table 1$)$.

Mechanical properties of the solvent-cast polymeric films are shown in Figure 1. The UTS and elongation at break were obtained. The blank solvent-cast polymeric film showed strength, which declined significantly following the addition of Eudragit ${ }^{\circledR} \mathrm{NE} 30 \mathrm{D}$ into solvent-cast polymeric films. The Eudragit ${ }^{\circledR}$ NE $30 \mathrm{D}$ and glycerin might move into polymer segments, spacing them farther apart by reducing the intensity of polymer-polymer interactions. This spacing facilitates the relative movement of macromolecules $(27,28)$. In addition, the UTS and elongation at the patch breaks decreased after the ionic liquid lidocaine/aspirin loading.

The thermal characterization of solvent-cast polymeric films containing ionic liquid lidocaine/aspirin for transdermal patches is shown in Figure 2; the thermal characterization of lidocaine, aspirin, and ionic liquid lidocaine/aspirin are known from previous studies $(25,26)$. Briefly, from Figure $2 \mathrm{~A}$, the melting point of lidocaine, aspirin, and ionic liquid lidocaine/aspirin were $77.75^{\circ} \mathrm{C}, 141^{\circ} \mathrm{C}$, and $93.50^{\circ} \mathrm{C}$, respectively. As seen in Figures $2 \mathrm{~B}$ and $2 \mathrm{C}$, the maximum temperature of thermal degradation of lidocaine was $240.2^{\circ} \mathrm{C}$ in the $116-288^{\circ} \mathrm{C}$ temperature range. However, aspirin underwent two stages of thermal decomposition: (I) the elimination of acetic acid and the formation of salicylic acid at a maximum temperature of $166.7^{\circ} \mathrm{C}$ in the $150-240^{\circ} \mathrm{C}$ temperature range, and (II) the elimination of $\mathrm{CO}_{2}$ and the formation of phenol at a maximum temperature of $325.5^{\circ} \mathrm{C}$ in the $300-360^{\circ} \mathrm{C}$ temperature range. The thermal decomposition of ionic liquid lidocaine/aspirin proceeded through one stage with the maximum temperature at $220.4^{\circ} \mathrm{C}$ in the $105-265^{\circ} \mathrm{C}$ temperature range. A similar observation was made (Figure $2 \mathrm{~A}$ ) for the DSC thermograms of blank solventcast polymeric films (FB01-FB03) and solvent-cast polymeric films containing ionic liquid lidocaine/aspirin for transdermal patches (F01-F03). Therefore, the drugs did not interact with the excipients in their solvent-cast polymeric films. Figures $2 \mathrm{~B}$ and $2 \mathrm{C}$ show the weight loss of all samples, indicating the first decomposition stage below $100^{\circ} \mathrm{C}$. This loss might have been due to moisture elimination $(29,30)$. The blank solvent-cast polymeric films showed two stages of weight loss: (I) in the $139-226^{\circ} \mathrm{C}$ temperature range, with maximum temperature at $184.23^{\circ} \mathrm{C}, 197.01^{\circ} \mathrm{C}$, and $191.68^{\circ} \mathrm{C}$, and (II) in the $221-327^{\circ} \mathrm{C}$ temperature range, with maximum temperature at $254.06^{\circ} \mathrm{C}, 245.98^{\circ} \mathrm{C}$, and $236.03^{\circ} \mathrm{C}$ for the $\mathrm{FB} 01$, $\mathrm{FB} 02$, and FB03 formulations, respectively. In contrast, the solvent-cast polymeric films containing ionic liquid lidocaine/aspirin showed only one stage of weight loss in the $178-317^{\circ} \mathrm{C}$ temperature range, with maximum temperatures at $244.95^{\circ} \mathrm{C}, 224.48^{\circ} \mathrm{C}$, and $214.55^{\circ} \mathrm{C}$ for formulation $\mathrm{F} 01, \mathrm{~F} 02$, and $\mathrm{F} 03$, respectively. As a result, the decomposition of the solvent-cast polymeric films containing ionic liquid lidocaine/aspirin was found to broadly peak in the $178-317^{\circ} \mathrm{C}$ temperature range, with maximum temperature at $214-245^{\circ} \mathrm{C}$, while the decomposition of the ionic liquid lidocaine/aspirin broadly peaked in the $105-265^{\circ} \mathrm{C}$ temperature range with a maximum temperature at $220.4^{\circ} \mathrm{C}$. Therefore, the ionic liquid lidocaine/aspirin was conclusively within the patch.

Figure 3 shows the XRD patterns of blank solvent-cast polymeric films (FB01-FB03) and solvent-cast polymeric films containing ionic liquid lidocaine/aspirin (F01-F03). These patterns showed a broad peak, which represented the amorphous state, implying that the ionic liquid lidocaine/aspirin was either converted into an amorphous form that was completely miscible or was solubilized in the transdermal patch components. 
Regarding the physicomechanical properties of the solvent-cast drug-containing patches, the DSC thermogram, TGA thermogram, DTG thermogram, and XRD pattern were similar to that of the blank polymeric film; therefore, the properties of the patch were not changed after loading the ionic liquid lidocaine/aspirin.

The surface morphology of the blank solvent-cast polymeric films (FB01-FB03) and solvent-cast polymeric films containing ionic liquid lidocaine/aspirin for transdermal patches (F01-F03) are shown in Figure 4. The surface of formulations FB03, F01, and F02 showed slight cracking because of the solvent's rapid evaporation during the preparation of the solvent-cast polymeric films. The surface of the blank solvent-cast polymeric films was smoother than the surface of transdermal patches. The surface of the transdermal patches showed a roughness, which was the result of the small particles and the pores of the lidocaine/aspirin distributed and inserted into the matrix of the polymeric films.

The lidocaine and aspirin drugs in solvent-cast polymeric films were extracted and analyzed by HPLC. Figure 5 shows the trend of drug content found in transdermal patches. The contents of lidocaine were $2.58 \pm 0.31,1.49 \pm 0.09$, and $1.39 \pm 0.22 \mathrm{mg} / \mathrm{cm}^{2}$ while the contents of aspirin were found to be $1.98 \pm 0.23,1.10 \pm 0.08$, and $1.08 \pm 0.16 \mathrm{mg} / \mathrm{cm}^{2}$ in the transdermal patches F01, F02, and F03, respectively. Beyond that, the encapsulation efficiency of the drug (expressed in percentage) was calculated as (actual drug content/theoretical drug content) ' 100 . The percentages of encapsulation efficiency of lidocaine and aspirin are given in Figure 5. Entrapment efficiency for formulation F01 (103.09 $\pm 12.36 \%$ for lidocaine and $98.95 \pm 11.65 \%$ for aspirin) was maximum and minimum for formulation F03 (55.47 $\pm 8.77 \%$ for lidocaine and $53.76 \pm 8.12 \%$ for aspirin). It was observed that the use of the Eudragit ${ }^{\circledR} \mathrm{NE} 30 \mathrm{D}$ significantly reduced the trends of entrapment efficiency for both lidocaine and aspirin drugs $(p<0.05)$. Meanwhile, the increasing ratio of Eudragit ${ }^{\circledR} \mathrm{NE} 30 \mathrm{D}$ showed slightly decreasing trends that were not significant $(p>0.05)$. These results may be because Eudragit ${ }^{\circledR}$ NE 30D increased the patches' hydrophilicity, leading to a decline in drug holding capacity $(4,5,31,32)$. Thus, the formulation F01 and F03 were used to study the in vitro release of the drug.

The selection of receptor medium to study the in vitro release of the drug used the equilibrium method to study the solubility of the pure drug at equilibrium concentration, as described in our previous publication (26). The in vitro releases of both lidocaine and aspirin are shown in Figure 6 . The cumulative release amounts of lidocaine drug were $107.85 \pm 29.96 \%$ and $102.66 \pm 26.43 \%$, while the cumulative release amounts of aspirin drug were $75.74 \pm 15.66 \%$ and $67.67 \pm 20.68 \%$ from formulation F01 and F03, respectively, after $12 \mathrm{hrs}$. The patterns of in vitro releases for both lidocaine and aspirin revealed significantly retarded drug release when the Eudragit ${ }^{\circledR} \mathrm{NE} 30 \mathrm{D}$ was added in solvent-cast polymeric films for transdermal patches. The cumulative amount of drug released from formulation F01 was high compared with drug release from formulation F03. This result could be attributed to the greater hydrophobicity of Eudragit ${ }^{\circledR} \mathrm{NE} 30 \mathrm{D}$, causing the drug to diffuse more slowly into the receptor medium. Thus, the patches' low hydrophilicity might be controlled by Eudragit ${ }^{\circledR}$ NE 30D, which is available in $30 \%$ aqueous dispersion of a neutral copolymer based on ethyl acrylate and methyl methacrylate $(33,34)$. When the cumulative amount of drug released per square centimeter of transdermal patches was plotted against time, the drugs' in vitro release profiles followed mixed zero-order and first-order kinetics (Table 3 ). The in vitro release profiles of the formulations did not fit into either zero-order kinetic $\left(r^{2}=0.7841-0.5056\right)$ or first-order kinetics $\left(r^{2}=0.9316-0.6098\right)$. However, the in vitro release profiles of the formulated transdermal patches followed Higuchi's equation $\left(r^{2}=0.9526-0.7662\right)$, which indicates that the release of the drug from the patch was governed by a diffusion mechanism $(32,35,36)$. In this context, the results obtained from Higuchi's model support the results of in vitro release profiles and the theory that the patches release the drug by a diffusion-dominated mechanism.

\section{Conclusion}

Matrix polymeric films were produced using different ratios of pectin and Eudragit ${ }^{\circledR} \mathrm{NE} 30 \mathrm{D}$, and glycerin was used as a plasticizer. Lidocaine and aspirin drugs formed an ionic liquid before mixing in a polymer solution. Matrix polymeric films were prepared by solvent casting in which solvent evaporation from a polymer solution leaves behind a continuous layer of the polymeric film. The Eudragit ${ }^{\circledR} \mathrm{NE} 30 \mathrm{D}$ significantly affected the mechanical properties that decreased the toughness and rigidity of the films. The transdermal patches' matrix polymeric film showed the amorphous state, and its thermal properties were unchanged from blank polymeric films. Surface images of the polymeric matrix film of transdermal patches revealed a continuous distribution of the drug. The physicomechanical properties of the patches did not change when ionic liquid lidocaine/aspirin was loaded. The trends of entrapment efficiency and in vitro release of lidocaine and aspirin drugs significantly decreased when the Eudragit ${ }^{\circledR} \mathrm{NE} 30 \mathrm{D}$ increased in the polymeric matrix film of transdermal patches. Higuchi's kinetic model indicated that a diffusion mechanism was responsible for the release of the drug from the patch. Thus, the solvent-cast polymeric films from two polymers, pectin and Eudragit ${ }^{\circledR} \mathrm{NE} 30 \mathrm{D}$, are suitable for transdermal patches loaded with an ionic liquid lidocaine/aspirin drug.

\section{Declarations}

\section{Acknowledgments}

We thank to Jebsen \& Jessen Ingredients (T) Ltd., Thailand for Eudragit ${ }^{\circledR}$ NE 30D as a polymer material in this work and College of Pharmacy, Rangsit University for financial support.

\section{Conflict of Interest}


The authors report no conflicts of interest. The authors alone are responsible for the content and writing of this article.

\section{References}

1. Cilurzo F, Minghetti P, Gennari CGM, Casiraghi A, Montanari L (2010) A novel polymethylmethacrylate hydrophilic adhesive matrix intended for transdermal patch formulations. Drug Deliv 17(3): 171-177

2. Suksaeree J, Charoenchai L, Monton C, Chusut T, Sakunpak A, Pichayakorn W, et al. (2013) Preparation of a pseudolatex-membrane for ketoprofen transdermal drug delivery systems. Ind Eng Chem Res 52(45): 15847-15854

3. Suksaeree J, Pichayakorn W, Monton C, Sakunpak A, Chusut T, Saingam W (2014) Rubber polymers for transdermal drug delivery systems. Ind Eng Chem Res 53(2): 507-513

4. Pichayakorn W, Suksaeree J, Boonme P, Amnuaikit T, Taweepreda W, Ritthidej GC (2012) Nicotine transdermal patches using polymeric natural rubber as the matrix controlling system: Effect of polymer and plasticizer blends. J Membr Sci 411-412(81-90

5. Pichayakorn W, Suksaeree J, Boonme P, Amnuaikit T, Taweepreda W, Ritthidej GC (2012) Deproteinized natural rubber latex/hydroxypropylmethyl cellulose blending polymers for nicotine matrix films. Ind Eng Chem Res 51(25): 8442-8452

6. Pichayakorn W, Suksaeree J, Boonme P, Taweepreda W, Amnuaikit T, C. Ritthidej G (2015) Transdermal nicotine mixed natural rubberhydroxypropylmethylcellulose film forming systems for smoking cessation: In vitro evaluations. Pharmaceut Dev Tech 20(8): 966-975

7. Suksaeree J, Prasomkij J, Panrat K, Pichayakorn W (2018) Comparison of pectin layers for nicotine transdermal patch preparation. Adv Pharm Bull 8(3): 401-410

8. Suksaeree J, Karnsopa P, Wannaphruek N, Prasomkij J, Panrat K, Monton C, et al. (2018) Use of isolated pectin from a cissampelos pareira-based polymer blend matrix for the transdermal delivery of nicotine. J Polym Environ 26(9): 3531-3539

9. Suksaeree J, Karnsopa P, Wannaphruek N, Prasomkij J, Panrat K, Pichayakorn W (2018) Transdermal delivery of nicotine using pectin isolated from durian fruit-hulls-based polymer blends as a matrix layer. J Polym Environ 26(8): 3216-3225

10. Suksaeree J, Monton C, Madaka F, Chusut T, Saingam W, Pichayakorn W, et al. (2015) Formulation, physicochemical characterization, and in vitro study of chitosan/HPMC blends-based herbal blended patches. AAPS PharmSciTech 16(1): 171-181

11. Suksaeree J, Charoenchai L, Madaka F, Monton C, Sakunpak A, Charoonratana T, et al. (2015) Zingiber cassumunarblended patches for skin application: Formulation, physicochemical properties, and in vitro studies. Asian J Pharm Sci 10(4): 341-349

12. Gupta V, Singh S, Srivarstava M, Ahmad H, Pachauri SD, Khandelwal K, et al. (2016) Effect of polydimethylsiloxane and ethylcellulose on in vitro permeation of centchroman from its transdermal patches. Drug Deliv 23(1): 113-122

13. Boateng JS, Stevens HNE, Eccleston GM, Auffret AD, Humphrey MJ, Matthews KH (2009) Development and mechanical characterization of solvent-cast polymeric films as potential drug delivery systems to mucosal surfaces. Drug Dev Ind Pharm 35(8): $986-996$

14. Amrutkar PP, Chaudhari PD, Patil SB (2012) Design and in vitro evaluation of multiparticulate floating drug delivery system of zolpidem tartarate. Colloids Surf B Biointerfaces 89(182-187

15. Kumria R, Nair AB, Al-Dhubiab BE (2014) Loratidine buccal films for allergic rhinitis: development and evaluation. Drug Dev Ind Pharm 40(5): 625631

16. Kumria R, Nair AB, Goomber G, Gupta S (2016) Buccal films of prednisolone with enhanced bioavailability. Drug Deliv 23(2): 471-478

17. Minghetti P, Cilurzo F, Casiraghi A, Molla FA, Montanari L (1999) Dermal Patches for the Controlled Release of Miconazole: Influence of the Drug Concentration on the Technological Characteristics. Drug Dev Ind Pharm 25(5): 679-684

18. Bica K, Rijksen C, Nieuwenhuyzen M, Rogers RD (2010) In search of pure liquid salt forms of aspirin: ionic liquid approaches with acetylsalicylic acid and salicylic acid. Phys Chem Chem Phys 12(8): 2011-2017

19. Miwa Y, Hamamoto H, Ishida T (2016) Lidocaine self-sacrificially improves the skin permeation of the acidic and poorly water-soluble drug etodolac via its transformation into an ionic liquid. Eur J Pharm Biopharm 102(92-100

20. Berton P, Di Bona KR, Yancey D, Rizvi SAA, Gray M, Gurau G, et al. (2017) Transdermal bioavailability in rats of lidocaine in the forms of ionic liquids, salts, and deep eutectic. ACS Med Chem Lett 8(5): 498-503

21. Park HJ, Prausnitz MR (2015) Lidocaine-ibuprofen ionic liquid for dermal anesthesia. AlChE J 61(9): $2732-2738$

22. Hough WL, Smiglak M, Rodríguez H, Swatloski RP, Spear SK, Daly DT, et al. (2007) The third evolution of ionic liquids: active pharmaceutical ingredients. New J Chem 31(8): 1429-1436

23. Pernak J, Sobaszkiewicz K, Mirska I (2003) Anti-microbial activities of ionic liquids. Green Chem 5(1): 52-56

24. Dobler D, Schmidts T, Klingenhöfer I, Runkel F (2013) Ionic liquids as ingredients in topical drug delivery systems. Int J Pharm 441(1): 620-627

25. Maneewattanapinyo P, Suksaeree J (2019) Development and validation of HPLC method for characterization of the acidic and basic drugs prepared into ionic liquid. Lat Am J Pharm 38(5): 961-967

26. Maneewattanapinyo P, Yeesamun A, Watthana F, Panrat K, Pichayakorn W, Suksaeree J (2020) Transdermal patches of lidocaine/aspirin ionic liquid drug-loaded gelatin/polyvinyl alcohol composite film prepared by freeze-thawed procedure. An Acad Bras Ciênc 92(2): e20191073:

20191071-20191012

Page 6/11 
27. Rudin A, Choi P, in: The Elements of Polymer Science \& Engineering (Third Edition). Rudin A, Choi P, eds. (Academic Press, Boston, 2013), pp. 231274

28. Godwin AD, in: Applied Plastics Engineering Handbook. Kutz M, ed. (William Andrew Publishing, Oxford, 2011), pp. 487-501

29. Pirayavaraporn C, Rades T, Tucker IG (2012) Determination of moisture content in relation to thermal behaviour and plasticization of Eudragit RLPO. Int J Pharm 422(1): 68-74

30. Yong V, Hahn HT (2007) Moisture absorption modeling using design of experiments. J Appl Polym Sci 103(3): 1539-1543

31. Gupta R, Mukherjee B (2003) Development and in vitro evaluation of diltiazem hydrochloride transdermal patches based on povidoneethylcellulose matrices. Drug Dev Ind Pharm 29(1): 1-7

32. Ubaidulla U, Reddy MVS, Ruckmani K, Ahmad FJ, Khar RK (2007) Transdermal therapeutic system of carvedilol: Effect of hydrophilic and hydrophobic matrix on in vitro and in vivo characteristics. AAPS PharmSciTech 8(1): E13-E20

33. Desai K-GH, Mallery SR, Holpuch AS, Schwendeman SP (2011) Development and in vitro-in vivo evaluation of fenretinide-loaded oral mucoadhesive patches for site-specific chemoprevention of oral cancer. Pharm Res 28(10): 2599-2609

34. Pendekal SM, Tegginamat KP (2012) Formulation and evaluation of a bioadhesive patch for buccal delivery of tizanidine. Acta Pharm Sin B 2(3): 318-324

35. Ritger PL, Peppas NA (1987) A simple equation for description of solute release II. Fickian and anomalous release from swellable devices. J Control Release 5(1): 37-42

36. Siepmann J, Peppas NA (2001) Modeling of drug release from delivery systems based on hydroxypropyl methylcellulose (HPMC). Adv Drug Deliv Rev 48(2-3): 139-157

\section{Tables}

Table 1 Ingredients of solvent-cast polymeric films containing lidocaine/aspirin for transdermal patches

\begin{tabular}{|c|c|c|c|c|c|c|c|}
\hline ient & $\begin{array}{l}\text { Pectin } \\
\text { (g) }\end{array}$ & $\begin{array}{c}\text { Eudragit }^{\circledR} \mathrm{NE} \\
30 \mathrm{D} \\
(\mathrm{g})\end{array}$ & $\begin{array}{c}\text { Glycerine }^{\mathrm{a}} \\
\text { (g) }\end{array}$ & $\begin{array}{l}\text { Ionic liquid Lidocaine- } \\
\text { aspirin drug } \\
(\mathrm{g})\end{array}$ & $\begin{array}{l}\text { Distilled water } \\
\text { qs. to } \\
\text { (g) }\end{array}$ & $\begin{array}{l}\text { Weight }^{\mathrm{b}} \\
\left(\mathrm{mg} / \mathrm{cm}^{2}\right)\end{array}$ & $\begin{array}{l}\text { Thickness }^{b} \\
\left(\mu \mathrm{m} / \mathrm{cm}^{2}\right)\end{array}$ \\
\hline 1 & 4.5 & 0 & 1.35 & - & 150 & $\begin{array}{c}64.60 \pm \\
4.69\end{array}$ & $\begin{array}{c}211.20 \pm \\
6.65\end{array}$ \\
\hline 2 & 4.5 & 2.25 & 2.025 & - & 150 & $\begin{array}{c}78.74 \pm \\
5.27\end{array}$ & $\begin{array}{c}222.00 \pm \\
7.62\end{array}$ \\
\hline$\overline{3}$ & 4.5 & 4.5 & 2.7 & - & 150 & $\begin{array}{c}83.78 \pm \\
7.96\end{array}$ & $\begin{array}{c}232.00 \pm \\
5.15\end{array}$ \\
\hline & 4.5 & 0 & 1.35 & 4.5 & 150 & $\begin{array}{c}65.04 \pm \\
6.15\end{array}$ & $\begin{array}{c}214.40 \pm \\
11.76\end{array}$ \\
\hline : & 4.5 & 2.25 & 2.025 & 4.5 & 150 & $\begin{array}{c}79.58 \pm \\
6.24\end{array}$ & $\begin{array}{c}226.00 \pm \\
11.64\end{array}$ \\
\hline ; & 4.5 & 4.5 & 2.7 & 4.5 & 150 & $\begin{array}{c}84.84 \pm \\
5.07\end{array}$ & $\begin{array}{c}235.60 \pm \\
13.94\end{array}$ \\
\hline
\end{tabular}

a The amount of glycerin was used at $30 \% \mathrm{w} / \mathrm{w}$ based on polymer

${ }^{\mathrm{b}}$ Avg. measurements from five different points on the patch

Table 2 Validation results of the analytical method

\begin{tabular}{|c|c|c|c|c|c|c|}
\hline \multirow[t]{2}{*}{ Drug } & \multirow{2}{*}{$\begin{array}{c}\text { Added standard concentration } \\
(\mu \mathrm{g} / \mathrm{mL})\end{array}$} & \multirow{2}{*}{$\begin{array}{c}\text { Accuracy } \\
\text { (\%recovery) }\end{array}$} & \multicolumn{2}{|c|}{ Precision (\%RSD) } & \multirow{2}{*}{$\begin{array}{c}\mathrm{LOD} \\
(\mu \mathrm{g} / \mathrm{mL})\end{array}$} & \multirow{2}{*}{$\begin{array}{c}\mathrm{LOQ} \\
(\mu \mathrm{g} / \mathrm{mL})\end{array}$} \\
\hline & & & Intra-day & Inter-day & & \\
\hline \multirow[t]{3}{*}{ Lidocaine } & 20.0 & 102.93 & \multirow[t]{3}{*}{0.03} & \multirow[t]{3}{*}{0.03} & \multirow{3}{*}{1.25} & \multirow[t]{3}{*}{4.15} \\
\hline & 40.0 & 98.76 & & & & \\
\hline & 60.0 & 97.19 & & & & \\
\hline \multirow[t]{3}{*}{ Aspirin } & 20.0 & 100.37 & \multirow[t]{3}{*}{0.01} & \multirow[t]{3}{*}{0.02} & \multirow[t]{3}{*}{1.33} & \multirow[t]{3}{*}{4.89} \\
\hline & 40.0 & 100.86 & & & & \\
\hline & 60.0 & 99.30 & & & & \\
\hline
\end{tabular}

Table 3 Kinetic release of lidocaine and aspirin from the transdermal patches 


\begin{tabular}{|c|c|c|c|c|c|c|c|c|c|c|c|c|}
\hline \multirow[t]{3}{*}{ Formulas } & \multicolumn{6}{|c|}{ Kinetic release of lidocaine } & \multicolumn{6}{|c|}{ Kinetic release of lidocaine } \\
\hline & \multicolumn{2}{|c|}{ Zero-order } & \multicolumn{2}{|c|}{ First-order } & \multicolumn{2}{|c|}{ Higuchi's model } & \multicolumn{2}{|c|}{ Zero-order } & \multicolumn{2}{|c|}{ First-order } & \multicolumn{2}{|c|}{\begin{tabular}{|l} 
Higuchi's model \\
\end{tabular}} \\
\hline & Equation & $\mathrm{R}^{2}$ & Equation & $\mathrm{R}^{2}$ & Equation & $\mathrm{R}^{2}$ & Equation & $\mathrm{R}^{2}$ & Equation & $\mathrm{R}^{2}$ & Equation & $\mathrm{R}^{2}$ \\
\hline F01 & $\begin{array}{c}y= \\
7.2392 \mathrm{x} \\
+ \\
40.7230\end{array}$ & 0.6865 & $\begin{array}{c}\mathrm{y}= \\
-0.7547 \mathrm{x} \\
+4.9298\end{array}$ & 0.9025 & $\begin{array}{c}y= \\
30.8700 x \\
+ \\
15.7000\end{array}$ & 0.9079 & $\begin{array}{c}y= \\
4.6278 \mathrm{x} \\
+ \\
38.3850\end{array}$ & 0.5056 & $\begin{array}{c}y= \\
-0.1033 \mathrm{x} \\
+4.0262\end{array}$ & 0.6098 & $\begin{array}{c}y= \\
21.1880 \mathrm{x} \\
+ \\
19.6140\end{array}$ & 0.7662 \\
\hline F03 & $\begin{array}{c}\mathrm{y}= \\
7.4435 \mathrm{x} \\
+ \\
30.5180\end{array}$ & 0.7841 & $\begin{array}{c}y= \\
-0.3966 x \\
+4.6826\end{array}$ & 0.9316 & $\begin{array}{c}y= \\
30.512 \mathrm{x} \\
+7.1346\end{array}$ & 0.9526 & $\begin{array}{c}\mathrm{y}= \\
4.6818 \mathrm{x} \\
+ \\
26.4700\end{array}$ & 0.6532 & $\begin{array}{c}y= \\
-0.0873 x \\
+4.2750\end{array}$ & 0.7644 & $\begin{array}{c}y= \\
20.16 \mathrm{x}+ \\
9.9138\end{array}$ & 0.8756 \\
\hline
\end{tabular}

\section{Figures}
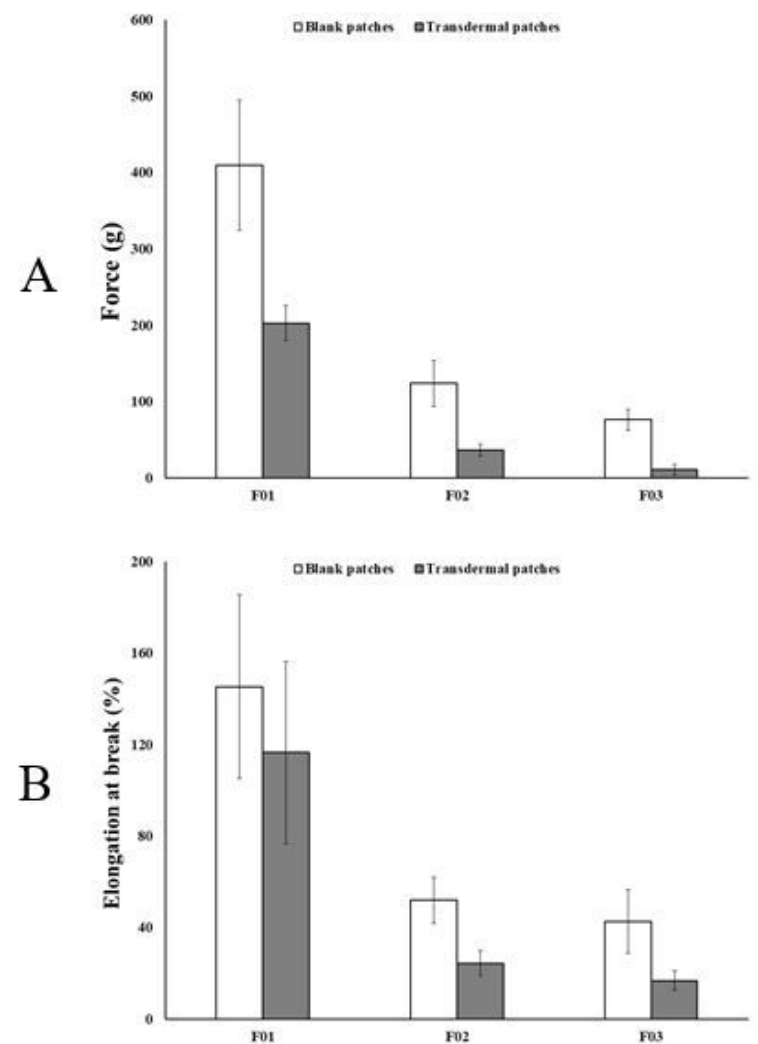

\section{Figure 1}

Mechanical properties of solvent-cast polymeric films containing lidocaine/aspirin for transdermal patches: (A) UTS and (B) percentage of elongation at break 
A
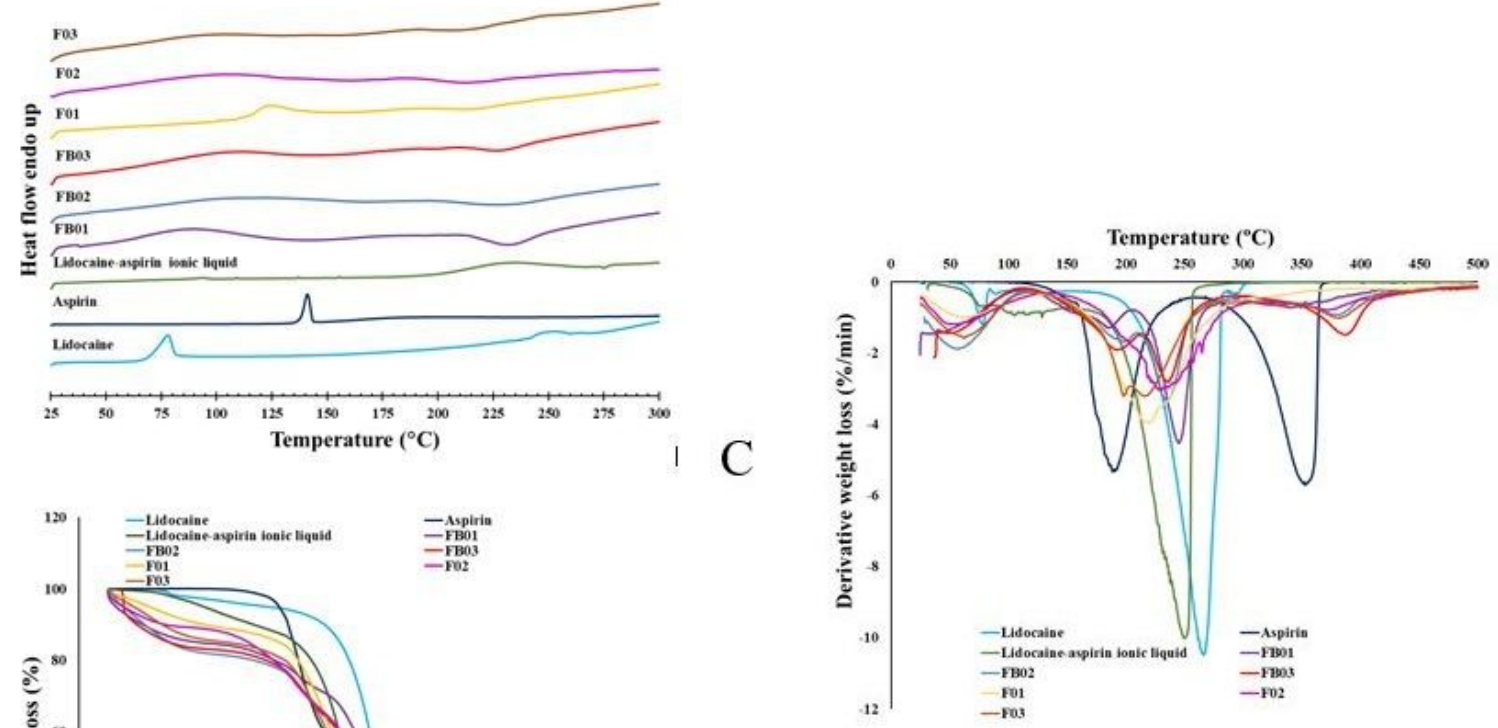

$\mathrm{B}$

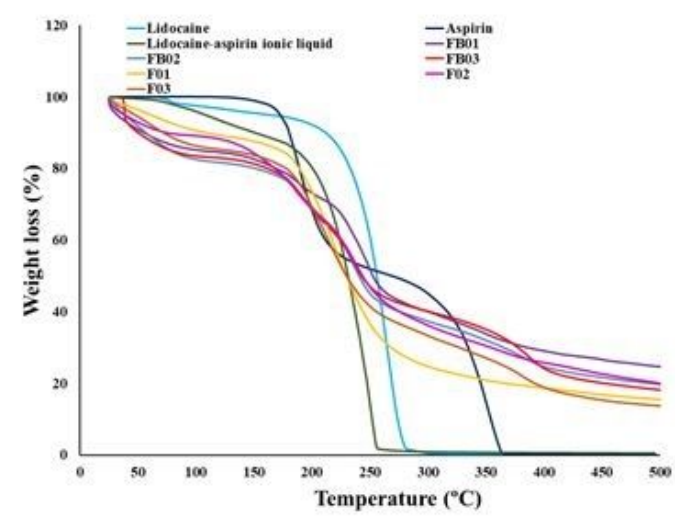

Figure 2

Characterization of solvent-cast polymeric films containing lidocaine/aspirin for transdermal patches: (A) DSC thermograms, (B) TGA thermograms, and (C) DTG thermograms

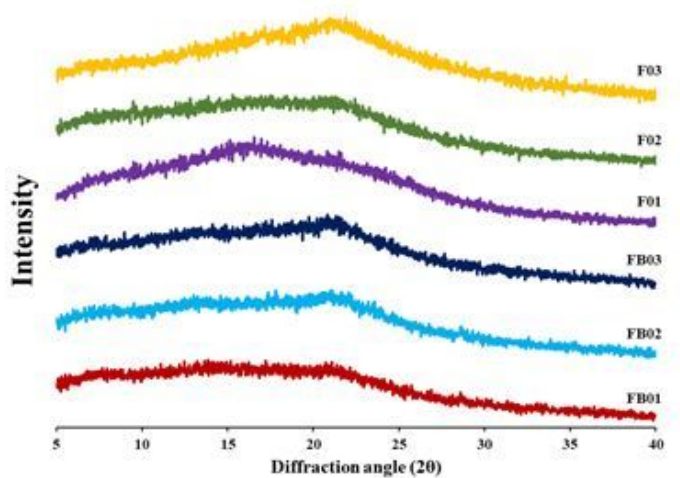

Figure 3

XRD patterns of solvent-cast polymeric films containing lidocaine/aspirin for transdermal patches 

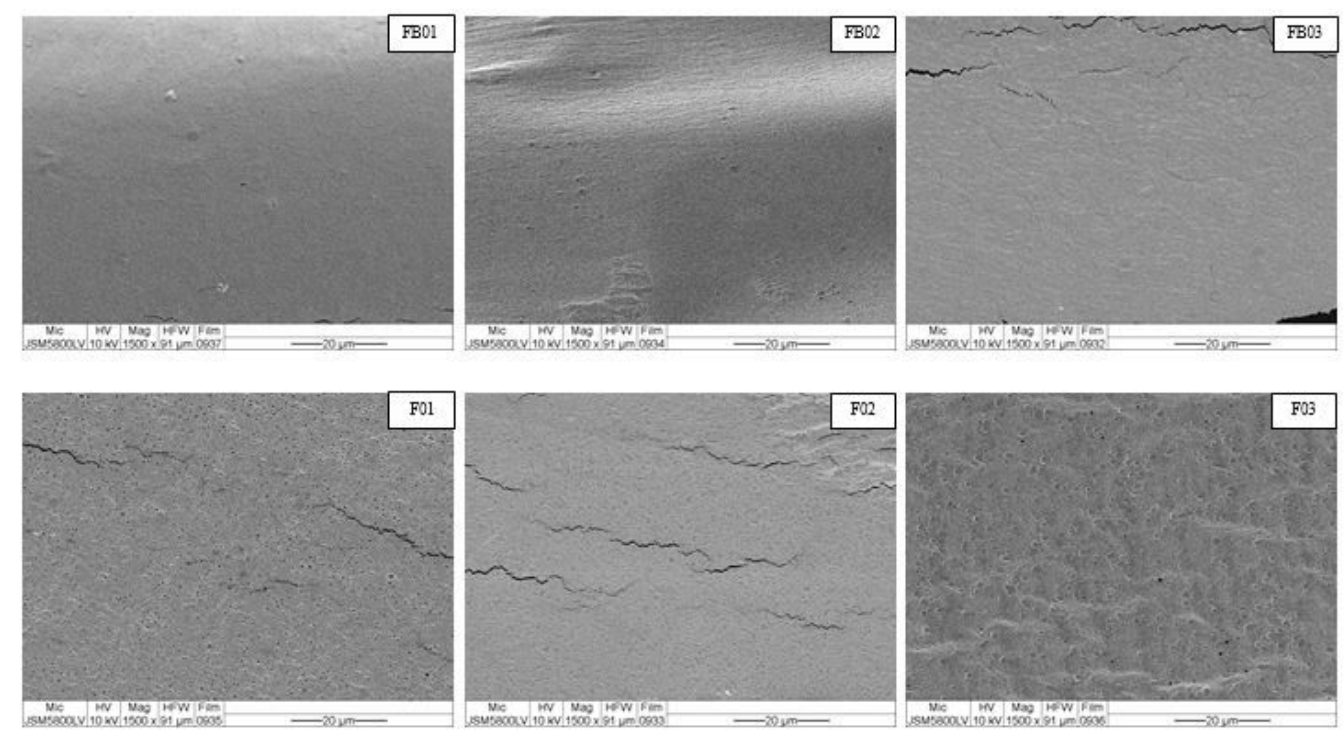

\section{Figure 4}

SEM images of solvent-cast polymeric films containing lidocaine/aspirin for transdermal patches
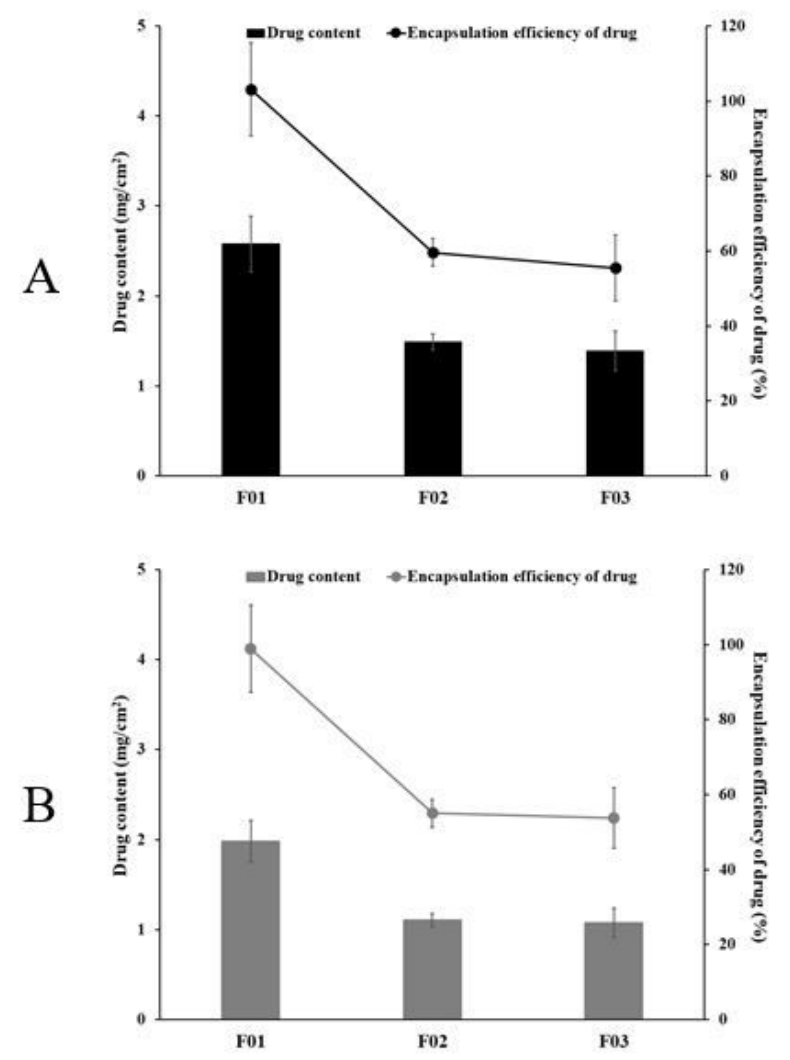

\section{Figure 5}

Drug content and encapsulation efficiency of $(A)$ lidocaine and $(B)$ aspirin in transdermal patches 

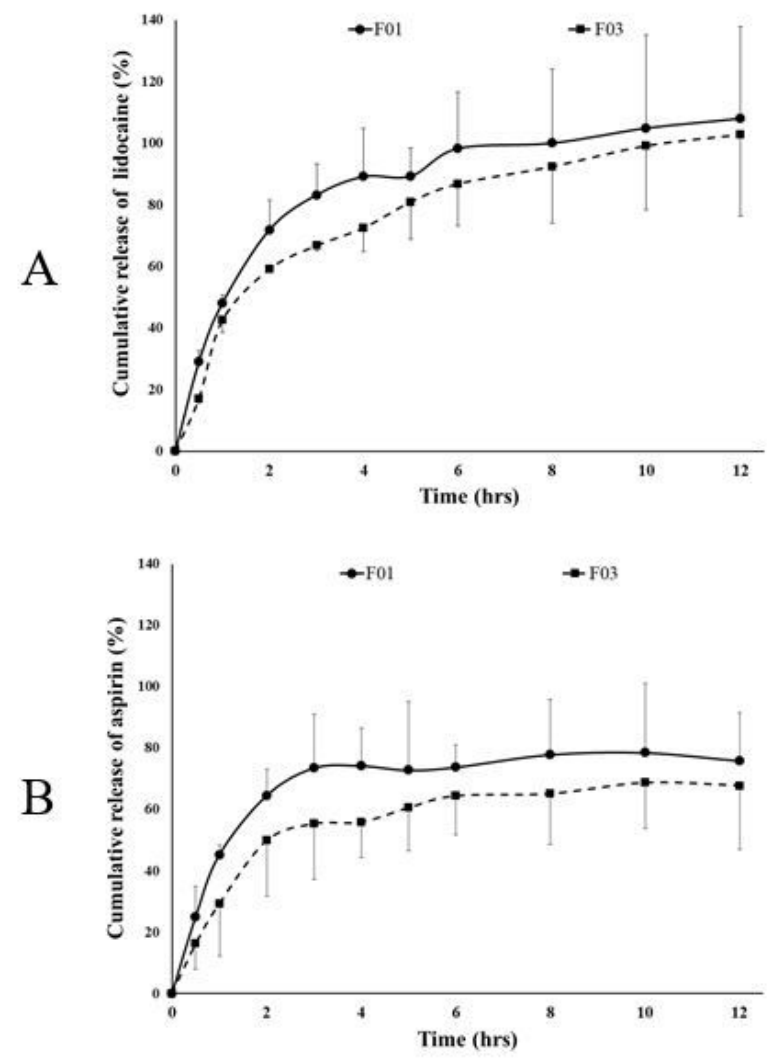

Figure 6

Release patterns of (A) lidocaine and (B) aspirin from transdermal patches 